\title{
Correction: (0-74) Virtual reality technology in anatomy education
}

Anatomy 2018;12(3):158 @2018 Turkish Society of Anatomy and Clinical Anatomy (TSACA)

\author{
$\underline{\text { Topuz }} \mathbf{Y}^{1}$, Özdener $\mathrm{DN}^{2}$, Verimli $\mathbf{U}^{3}$ \\ ${ }^{1}$ Department of Information Technologies and Security, Beykoz University, Istanbul, Turkey \\ ${ }^{2}$ Department of Computer Education and Instructional Technology, Marmara University Atatiirk Faculty of Education, Istanbul, Turkey \\ ${ }^{3}$ Department of Anatomy, School of Medicine, Marmara University, Istanbul, Turkey
}

Author names for abstract of poster presentation published in Volume 12, Supplement 2, September 2018, page S140; O-74 "Virtual reality technology in anatomy education" is erroneously published as: Topuz Y, Özdener DN. Corrected version is as follows: Topuz Y, Özdener DN, Verimli U.

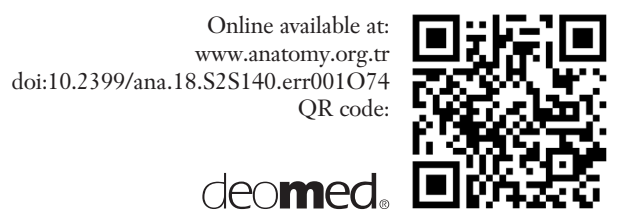

Correspondence to: Yasemin Topuz, MD

Department of Information Technologies and Security,

Beykoz University, Istanbul, Turkey

This is an open access article distributed under the terms of the Creative Commons Attribution-NonCommercial-NoDerivs 3.0 Unported (CC BY-NCND3.0) Licence (http://creativecommons.org/licenses/by-nc-nd/3.0/) which permits unrestricted noncommercial use, distribution, and reproduction in any medium, provided the original work is properly cited. Please cite this article as: Topuz Y, Özdener DN, Verimli U. Correction: (O-74) Virtual reality technology in anatomy education. Anatomy 2018;12(3):158. 